\title{
Material Break
}

National Cancer Institute

\section{Source}

National Cancer Institute. Material Break. NCI Thesaurus. Code C62973.

Problem associated with undesired damage or breakage of those materials used in the device construction. 